УДК 821.133.1'06-2Шмітт:1

DOI https://doi.org/10.24919/2308-4863/34-1-22

\author{
Ольга ВАСИЛЬСВА \\ orcid.org/0000-0003-3654-787 \\ аспірант кафедри романської філології та перекладу, \\ викладач кафедри німецької та романської мов \\ факультету іноземних мов \\ Харківського національного університету імені В. Н. Каразіна \\ (Харків, Україна) oluni4ka53vasi@gmail.com
}

\title{
ДИСКУРС ФІЛОСОФІЇ ПРОСВІТНИЦТВА В ДРАМАТУРГІЇ ЕРІКА-ЕММАНЮЕЛЯ ШМІТТА
}

\begin{abstract}
Статтю присвячено вивченню драматичних творів Еріка-Емманюеля Шмітта - відомого франкомовного письменника сучасності. Простежено шлях формування філософської думки драматурга та вплив ідей митиів доби Просвітництва на ичей процес, розглянуто роль його творчості в контексті літературного процесу XX-XXI століття. У статті для дослідження заявленої проблематики застосовувалися порівняльно-історичний, порівняльно-типологічний і структурний методи, які дали змогу протиставити драматичні твори Еріка-Емманюеля Шмітта іншим літературним феноменам, докладно дослідити особливості організації сюжетів, художніх образів та їхніх систем у творах иңього автора та виокремити його творчі надбання на літературній ниві епохи постмодернізму. Виокремлено один із ключових факторів у формуванні філософських світоглядних тенденцій Еріка-Емманюеля Шмітта, а саме - написання дисертації про Дені Дідро та знайомство з іншими відомими митиями епохи Просвітництва. Варто зазначити, щчо, працюючи над своӥм науковим дослідженням, письменник не оминув вивчення тогочасних тенденцій у філософії та літературі, зокрема драматургї. Знання та розуміння ідей і переконань митиів доби Просвітництва неабияк вплинули на формування філософської думки Шмітта: він надихався їхньою вірою в можливості людського пізнання, розглядав людину не тільки як чутливу, але $і$ як розумну істоту; як і просвітителі, франиузький письменник звертається до метафізичного способу мислення різноманітних релігійних тем. Автор переконаний, щзо філософ повинен уміти змішувати смішне із серйозним. Філософію не треба ховати за пафосними фразами і складними текстами, тому Шмітт узяв на себе відповідальність говорити з людьми просто про складне і ставиться до изього завдання як до місії. Під час аналізу авторського стилю Шмітта зроблено висновок, щзо загалом, його духовний розвиток відбувався переважно під впливом мислителів епохи Просвітництва, тому в творчості драматурга використано принципи та прийоми, притаманні творчості просвітителів. Такі тендениї можна простежити більш детально в наведеному у статті драматичному творі «Гість».
\end{abstract}

Ключові слова: n’єса, «Гість», сучасна франкомовна драматургія, Ерік-Емманюель Шмітт, Дідро, Просвітництвов.

\section{Olha VASYLIEVA, orcid.org/0000-0003-3654-7879 \\ Graduate Student at the Department of Romance Philology and Translation, Lecturer of the Department of German and Romance Languages of the Faculty of Foreign Languages V. N. Karazin Kharkiv National University (Kharkiv,Ukraine) oluni4ka53vasi@gmail.com}

\section{DISCOURSE OF THE PHILOSOPHY OF THE ENLIGHTENMENT IN THE THEATRE PLAYS OF ERIC-EMMANUEL SCHMITT}

This article studies the plays by Eric-Emmanuel Schmitt - a famous French writer of the modernity. The article observes the way of formation of the playwright's philosophical thought and the influence of ideas of the Enlightenment's artists on this process and it analyses the role of his work in the context of the literary process of the XX-XXI century. The article used comparative-historical, comparative-typological and structural methods to study the stated issues, that helps to contrast the dramatic works of Eric-Emmanuel Schmitt with other literary phenomena, to investigate in detail the peculiarities of the organization of plots, artistic images and their systems in the works of this author and to emphasize his creative achievements in the literary field of the postmodern era. One of the key factors in the formation of philosophical worldviews of Eric-Emmanuel Schmitt is the work on his thesis about Denis Diderot and acquaintance with other famous artists of the Enlightenment. It should be noted that while working on his research, the writer did not miss the opportunity to study a contemporary trends in philosophy and literature, including drama. Knowledge and understanding of the 
ideas and beliefs of artists of the Enlightenment influenced a lot the formation of Schmitt's philosophical thought: he was inspired by their belief in the possibility of human cognition, considered man not only as a sensitive but also as an intelligent being; according to the Enlightenment's ideas, the French writer turned to a metaphysical way of thinking and various religious topics. The author is convinced that the philosopher must be able to mix the funny with the serious. Philosophy should not be hidden behind pathetic phrases and complex texts, so Schmitt took it upon himself to speak to people simply about the complicated things and treats this task as a mission. Analyzing Schmitt's authorial style, we can summarize that in general, his spiritual development took place mainly under the influence of the artists of the Enlightenment, so the playwright's work used the principles and techniques inherent in the work of educators. Such tendencies can be traced in more detail in the play "Guest" given in the article.

Key words: theatre play, "Guest", modern French-language drama, Eric-Emmanuel Schmitt, Diderot, Enlightenment.

Постановка проблеми. Сучасний французький автор Ерік-Емманюель Шмітт належить до найяскравіших постатей літературного процесу межі XX-XXI століття, серед яких він посів особливе місце завдяки створенню насамперед драматичних творів, у яких, беручи за основу переважно релігійні та історичні мотиви (наприклад, у п'єсах), описує свої рефлексії щодо загальнолюдських морально-етичних цінностей. Його успіх пояснюється прагненням поєднати два типи письма: масовий та елітарний, вправним поєднанням гумору та метафізичних концепцій, чим Шмітт намагається залучити читача до діалогу, так само як це робив відомий філософ Дені Дідро, творчість якого надихнула письменника до створення його найвидатніших творів.

Перу Еріка-Емманюеля Шмітта належить більш ніж сорок різноманітних творів (близько двадцяти 3 них - драматичні твори), за них він відзначений низкою премій і нагород, серед яких: премія Мольєра в категорії «Найкращий автор» (1994 р. за п’єсу «Гість»), премія Мольєра в категорії «Найкраща постановка», театральна премія Французької академії (2001 р. за весь його творчий добуток), Німецька книжкова премія та премія Квадрига 3 формулюванням «Мудрість сміху», літературна премія Ротарі (2005р.). За мотивами його творів було знято п'ять кінофільмів, його твори перекладено більш ніж сорока мовами, а п'єси ставлять у театрах усього світу. Знайомство України зі Шміттом розпочалося 1999 р. 3 постановки Львівським національним театром ім. М. Заньковецької його п’єси «Загадкові варіації». До сьогодні це знайомство продовжується численними театральними постановками та перекладами його прозових творів.

Аналіз досліджень. Е.-Е. Шмітт перебуває в перманентному пошуку нових жанрових форм, які змогли б доступно та зрозуміло відобразити його філософські погляди, що $є$ поштовхом для багатьох вітчизняних науковців вивчати його творчий шлях, серед них: М. І. Логвиненко, Т. В. Бовсунівська, А. С. Сорокіна, О. О. Ленькова, Є. М. Васильєв та інші вчені. Успіх творів Е.-Е. Шмітта не можна порівняти 3 теоретичним та історико-літературним вивченням його творчості. Спроби його осмислення - і в Свропі, і в Україні - базуються передусім на аналізі філософемно-екзистенційного дискурсу романів письменника, проблематики дитинства тощо.

Але й сьогодні поза увагою науковців залишається драматургічна спадщина Е.-Е. Шмітта, вона досі не отримала належного літературознавчого прочитання, тому актуальність нашої роботи пояснюється потребою більш грунтовного вивчення драматургічного надбання письменника.

Метою статті $\epsilon$ аналіз проблематики та поетики драматичних творів Еріка-Емманюеля Шмітта (у дослідженні для досягнення поставленої мети взято драматичний твір Шмітта «Гість»).

Мета й завдання визначили застосування таких методів: порівняльно-типологічного - 3 метою зіставлення драматичних творів Е.-Е. Шмітта 3 іншими літературними феноменами; порівняльноісторичного, який дасть змогу виокремити драматургічну спадщину письменника на літературній ниві періоду XX - початку XXI століття; структурного, що допоможе в детальному дослідженні особливостей організації сюжетів, художніх образів та їхніх систем у творах Е.-Е. Шмітта.

Виклад основного матеріалу. Ерік-Емманюель Шмітт - письменник, який пропагує підхід до філософії як до особливого літературного жанру, що виражається в процесі інтеграції філософії та художньої літератури; метою цього підходу є надати своїм філософським ідеям і міркуванням правильної літературної форми.

Оптимізм є основним складником світогляду письменника, який у його творах знаходить форми певних естетичних принципів. Саме на їхньому рівні письменник розгортає полеміку із сучасним загальнокультурним плином, відомим як постмодернізм. Його песимізму, оформленому в мистецтві під виглядом іронічного дискурсу, принципу гри, нестійкого універсуму Шмітт протиставляє позитивну програму життя. Її змістом є реабілітація загальнолюдських цінностей і відновлення внутрішнього морально-етичного стрижня осо- 
бистості, розхитаного естетикою постмодернізму. Ця програма живиться ідеалами епохи Просвітництва та ідеями релігійного екзистенціалізму. Перші уможливили віру письменника в людину, другі - визначили коло проблем, загальних для всього людства, i шлях їх розв'язання - віру в Бога.

Характер зв'язку творчості Шмітта із сучасним філософсько-естетичним напрямом постмодернізму можна визначити як проблемний. Шмітт намагається протиставити себе постмодернізму, відкидаючи, зокрема постмодерністську чутливість, іронічний дискурс, песимізм, ігрове начало. Однак Шмітт усе ж не зміг уникнути його впливу. Творчу манеру письменника вирізняють плюралізм і демократичність поглядів (хоча підставою для них служить освітянський компроміс, а не постмодерністська естетизація іншої, альтернативної дійсності), діалогізм (якому письменник повертає класичне, а не постмодерністське ігрове значення), синтез філософії і художньої літератури (висхідний своїм корінням до ідей Просвітництва), інтертекстуальність, підвищений інтерес до проблеми людини і морального вибору.

Піком розвитку постмодерних ідей заведено вважати 1980-ті роки. У цих же роках Е.-Е. Шміт отримує філософську освіту в елітній вищій школі, де він навчався в одного 3 основоположників постмодернізму - Жака Дерріди. Простежуючи тенденції постмодернізму у всій творчості Шмітта, можна виявити як спільність позицій, так і розбіжності в них щодо постструктуралістських ідей Дерріди. Наприклад, Шмітт погоджується 3 підходом Дерріди до філософії як «особливого літературного жанру», що виражається в процесі інтеграції філософії та художньої літератури (Кірєєва, 2004: 200). Ця спільна риса споріднює ix із просвітителями, які свого часу освоїли майстерність надавати своїм філософським ідеям і міркуванням правильної літературної форми.

Загалом, духовний розвиток Шмітта відбувався переважно під впливом мислителів епохи Просвітництва. Під час написання своєї дисертації про Дідро, який був яскравим представником філософської думки тієї епохи, письменник не міг оминути вивчення тогочасних тенденцій у філософії та літературі, зокрема драматургії. Погляди Д. Дідро мали неабиякий вплив на формування філософської думки Шмітта: він надихався вірою просвітителя в можливості людського пізнання, розглядав людину не тільки як чутливу, але і як розумну істоту, визнаючи, що вона одночасно i музикант, й інструмент. Дідро для Шмітта $є$ прикладом того, яким повинен бути письменник: на його думку, він має вміти висловити в зрозумілій доступній формі роздуми над складними, а іноді й зовсім нерозв' язуваними питаннями, втілювати філософські ідеї в казках, п’єсах, діалогах. Близьким у роботі Дідро для Шмітта $є$ і те, що філософ Просвітництва із самого початку не претендує на істину в кінцевій інстанції. Тобто він може виносити на розгляд різноманітні питання, вагатися потім у відповідях на них і в кінцевому етапі так відповіді на ці писання і не знайти. У твоpax Шмітта часто можна натрапити на такі прийоми: після прочитання п'єси читач не може чітко сформувати якусь одну ідею, адже головна дійова особа чи герой самі так і не віднайшли істинного пояснення подій чи своїх власних думок. Зокрема, у п'єсі «Гість» відкритим залишається питання появи загадкового незнайомця та його походження (чи це і справді був Бог, чи реальна людина, чи лише плід уяви Фройда).

Ще однією визначною рисою творчості Шмітта $€$ звернення до різноманітних релігійних тем. Найбільш помітно це розкривається у твоpax «Євангеліє від Пілата», «Пан Ібрагім та квіти Корану», «Ніч у Валоні» та інших. Теологічна база його драматичних творів становить іноді визначну роль в аналізі їхнього філософського підгрунтя. Якщо проводити паралель із мисленням Дідро щодо цього, то відомо, що філософ виступав проти церкви, критично ставився до християнського віровчення. Він ставив під сумнів Біблію, вважаючи, що всі книги Біблії написані священнослужителями в різний час. Він писав, що в усіх релігіях від імені Бога говорили люди. Різко критикував дива, про які повідомляє Біблія. Вказував, що дива - безглуздість, яка доводиться за допомогою протиприродного явища. Віряни через свою релігійність беруть очікуване за дійсне, дива відбуваються там, де в них вірять. Він називав дива міфами, які подібні до міфів язичницьких релігій. Гостро критикував християнське вчення про пекло й муки, вважаючи, що релігійні догмати лише залякують людей, тероризують їх. Дідро вважав, що релігія не $\epsilon$ опорою моральності, хоча й вважав, що атеїзм сам собою ще не створює моральності. Потрібне цілеспрямоване поширення моральних принципів. Він не вважав, що людина від народження наділена злом і пороками, i був переконаний, що справедливе суспільство, яке спирається на справедливі закони, $\epsilon$ передумовою утвердження моральності (Блінніков, 1999: 135-136). Щодо Шмітта, то його ставлення до віри в Бога залишається невизначеним: будучи віруючим агностиком, автор не має точної відповіді на питання про існування вищих сил. Це помітно в п’єсі «Гість», де Фройд, будучи атеїстом, дозво- 
ляє собі відкритися Богові, яким він уявляє незнайомця. Ця віра допомагає психологу зазирнути до своєї душі та переглянути деякі свої погляди, віднайти відповіді на питання, що турбували та протягом тривалого часу залишалися без відповіді.

Просвітництво, до ідей якого так тяжіє Шмітт, було не тільки епохою філософії, але й епохою театру. Як і митці Просвітництва, французький письменник захоплений драматургією. Услід за Дідро, Шмітт визнає, що мистецтво театру має специфічні особливості, що роблять твори унікальними i не мають аналогів в інших родах $\mathrm{i}$ видах мистецтва. Життя саме йде назустріч театру, підказуючи цікаві сюжети й колізії, наповнюючи старі форми новим змістом. Для просвітителів викриття чинного порядку, зривання масок - головні завдання драматургії (Зарва,2009: 54). Шмітт має за мету пошук відповідей на питання, які його хвилюють. Він звільняється від гострої соціальної проблематики, властивої драматургам Просвітництва, і зосереджується на внутрішньому світі людини. Властива сучасному мистецтву діалогічність заміщає в творчості Шмітта категоричність соціальної критики просвітителів. Для автора діалог - це крок на шляху до істини. 3 цієї причини він згадує людей, які вміли вести бесіду і якоюсь мірою змінили світ: Сократ, Ісус, Фройд.

Просвітництво близьке Шмітту в головному його принципі: скеровувати людей до Добра i Справедливості. Звичайно, як представник зовсім іншої, сучасної епохи, Шмітт не дотримується всіх філософських канонів просвітителів, але риси його творів далеко не тотожні й постмодерну.

Для сучасної людини, яка втратила себе в «можливих світах» і «загралася» в їх інтерпретації, письменник пропонує повернутися до простих істин, а також відновити у своїх правах ідеї гуманізму, тобто надати пріоритету своїй особистості як унікальній цілісній системі, схильній до самоактуалізації, до вільної реалізації свого творчого потенціалу, до зміцнення віри в себе та досягнення свого ідеального «Я» (Ковалів, 2007: 246).

Крім того, орієнтація на ідеали Просвітництва дає можливість Шмітту повернути буттю структурність і гармонійну організацію, оскільки ця епоха викликає із небуття метафізичний спосіб мислення. Письменник не лише повертає метафізику, розвінчану постмодернізмом (зокрема, Ж. Дерріда виступав із критикою «метафізичного способу мислення»), але й стверджує ієрархічну структуру універсуму з ідеєю вищого початку.

У результаті постмодерністському представленню про світ як хаос, що виник внаслідок кризи в сфері науково-природничого знання на початку
XX століття, Шмітт протиставляє світ-космос, гармонійний універсум. Своїми творами він скасовує постмодерністську чутливість, що розуміється як «відчуття світу як хаосу». Постмодерна філософія відкидає такі поняття, як Бог, істина, розум, сенс життя. Відмовляючись від універсальної Істини, постмодернізм, відповідно, проголошує наявність самостійно цінних думок, що не претендують на абсолют, але мають рівні права на існування, що веде до руйнування цілісної картини світу. У своїх творах Шмітт не скасовує постмодерністський принцип різноманіття та плюралізму, але ставить над ними ідею Бога, який об'єднує в собі все це різноманіття і водночас є незаперечним джерелом Справедливості й Істини, тобто, на відміну від постмодернізму, письменник визнає існування універсальної Істини, основи якої становлять любов і повага до Людини (Маньковська, 1998: 130-132).

Шмітт звертається до пошуків «кінцевих істин» (яких часто так і не знаходить). Він використовує так звані метафізичні розповіді. Вони виступають у формі міфу, релігії, літературнохудожньої традиції, психології. Спираючись на ці системи, Е.-Е. Шмітт повертає людину на шлях пошуку істин, тоді як постмодерністська філософія відмовляла йому в цьому. Ще один фактор, який відрізняє авторський стиль Шмітта від традиційного постмодерністського, стилю пов'язаний iз філософією мови. Специфіка філософії мови Еріка-Емманюеля Шмітта, з одного боку, базується на діалогічному дискурсі, а $з$ іншого - виявляється в сфері комічного - у гуморі.

Оскільки Ідеалу не існувало, людині залишалося лише блукати серед нескінченної кількості дійсних можливостей. На відміну від іронії та сатири, гумористична позиція не передбачає вибору, а лише спостереження і констатування, тому вона не агресивна. В основі гумору лежить відхилення від норми або стереотипу, до того ж відхилення і норма в гуморі являють собою «єдність у контрасті». Для гумористичного світосприйняття характерне прийняття дійсності такою, яка вона $\epsilon$, без осуду й відторгнення. Для Шмітта важливо показати, що Ідеал і дійсність перебувають не в антагоністичних відносинах домінування першого над другим, а в стосунках рівно можливих, і взаємно визнають одне одного, а засобом для досягнення цієї мети стає гумор. Діалог у Шмітта оголює проблематичність життя, а гумор, не заперечуючи й не висміюючи іiї, допомагає з нею примиритися. У своєму творі «Оскар і Рожева Пані» автор порушує дуже хворобливу тему сучасності - рак. Ця тема, особливо в кон- 
тексті дитинства, є дуже гострою та проблемною, але Шмітт у своєму творі через образи та символи пропагує звернення не до трагізму, а до інших явищ: дружби, розуміння, усвідомлення, боротьби та віри, незважаючи ні на що.

Письменник проповідує гуманізм, основу якого становлять філософські питання, що зачіпають основи людського буття. Формування глибинного філософського пласта у драматичних творах забезпечується не тільки зверненням Шмітта до основоположних питань людського буття, але й завдяки дублюванню основного сюжету сюжетом притчовим.

Як було зазначено вище, однією з головних у творчості як просвітителів, так і Шмітта $\epsilon$ релігійна тема. Просвітителі були одностайні в розумінні церкви як соціального інституту, кажучи про неї як про цитадель фанатизму й невігластва. Питання ж про існування Бога було предметом гострих суперечок між ними. Серед філософів епохи Просвітництва були як атеїсти, так і деїсти (деїзм - учення, згідно з яким Бог, створивши світ, більше не втручається в його справи та закономірний перебіг подій) (Маньковська, 2016: 120). У творчості Шмітта клерикальна тема корелює 3 питанням існування Всевишнього, якому присвячено деякі відомі твори автора: «Свангеліє від Пілата», «Оскар і Рожева Пані». У п’єсі «Гість» (Le Visiteur) Шмітт розкриває деїстську концепцію невтручання словами самого Бога: «Тоді, коли я зробив людей вільними, я втратив усю мою владу над ними» (Schmitt, 2008: 98).

Цей твір широка публіка змогла побачити й оцінити у 1993 році. Події розгортаються навколо видатного психоаналітика Зигмунда Фройда та його родини, що живуть у Відні під час Другої світової війни. Він тяжко переживає перемогу нацизму, його доньку Анну забирають до гестапо, і він лишається на самоті. Тут автор також вводить тему війни, зокрема тему переслідування єврейського народу та жахливих наслідків, які наставали за всіма тими подіями. У деяких діалогах Анни, Фройда та офіцера можна відчути протест, відчай, безвихідь, страх людей перед тогочасним режимом: «...Але тут грабують і знущаються 3 людей чистіше, ніж у Німеччині. Я сама бачила, як штурмовики волокли старого робітника 3 дружиною, щоби змусити їх вичистити 3 тротуарів написи на захист Шушніга. Натовп кричав: «Нехай жиди попрацюють! Давно пора!», «Спасибі фюреру - знайшов їм роботу!» Поруч, за два кроки, били господаря бакалійної крамниці на очах у дружини і дітей... А ще подалі лежали тіла євреїв, які не стали чекати, поки за ними при- йдуть, і викинулися з вікна... Ти маєш рацію, тату, нацистів у Відні немає... для цієї мерзоти треба придумати слівце сильніше» (Schmitt, 2002: 18).

Після того як офіцер забрав Анну, яка сміливо обстоювала справедливість бурхливим діалогом, до гестапо, у кімнаті Фройда несподівано 3'являється Незнайомець і починає вести з психологом незвичайну бесіду. Зрозуміти, ким є цей чоловік, досить важко, адже він говорить загадками, але $з$ його слів можна зробити висновок, що це $є$ сам Бог... чи, можливо, хворому і немічному чоловікові це лише мариться. В їхньому діалозі дуже багато питань і протиріч, що $є$ виявом особливого філософського стилю письма автора неважливо знайти фінальну істину й відповісти на всі запитання, а герой, який ці питання ставить, увесь час не вагається з відповіддю чи й зовсім не може знайти їі. Якщо це Бог, то чому Він прийшов саме до нього, до людини, чиї вірування зовсім не $\epsilon$ релігійними? Чому не прийшов до людей, які називають себе пророками та посланцями Бога на Землі? На це Незнайомець відповідає, що говорити зі своїми однодумцями надто нудно, до того ж вони вже й самі краще знають, що їм і яким чином ïх нести в маси. Так автор в одному творі зіштовхує два поняття - атеїзм і деїзм. Згодом Фройд переконує себе, що незнайомий чоловік усе ж ніхто інший, як Бог, i, відкривши йому душу, починає ставити ті запитання, які хотів би поставити самому Господу. Після повернення дочки Незнайомець зникає і їхній діалог закінчується. Чи зміг Незнайомець донести свою істину до вченого, чи був ним почутий? Знову відкрите питання філософський сумнів, який автор вводить у п'єсу.

Як уже було згадано вище, Шмітт перебуває в перманентному пошуку нових жанрових форм і вдало варіює їх у своїх творах. У цій п’єсі ми також можемо простежити певний вплив епохи Просвітництва на творчість Шмітта, а також його тяжіння до жанрового розмаїття. Річ у тім, що одним із вбудованих у п'єсу «Гість» жанрових утворень $\epsilon$ філософська повість Вольтера. У ній ідеться про подорожі героя, про здобуття досвіду, про пошук відповідей на вічні питання. У Шмітта Фройд подорожує в часі і просторі, проте завдяки Незнайомцеві протягом бесіди змінюються його погляди. Як і у філософській повісті Вольтера, герой пізнає інші істини й починає сумніватися в правильності істин, з якими він прошов по життю. Варто згадати і казку - оповідання, метою якого є зацікавити читача виконати певну виховну функцію. Такий різновид казки, як філософська, покликана спонукати до роздумів $\mathrm{i}$ знайти відповіді на складні питання, часом алего- 
ричні або символічні. Отже, акцент у такій казці робиться не на чудове, а на філософське. Фройд живе в матеріальній дійсності, у певному часі й позначеній точці простору, умовно будучи нашим сучасником із властивою йому манерою розмовляти, думати, сумніватися. Дивне, здавалося б, відсутнє або навіть неможливе. Але саме таємничого й дивного характеру набуває сам факт бесіди Фройда і Бога (?). Ще одне епічне жанрове утворення, до якого має стосунок «Гість», - це притча, яка зі змістовного боку характеризується тягою до глибини і мудрості релігійного порядку. Світ речей згадується в ній лише в разі потреби, дійові особи - суб'єкти етичного вибору, а не об'єкти творчості. П'єса «Гість» від притчі успадковує глибинний сенс дії, що розгортається на сцені, за мізерності його зовнішнього оформлення та мінімальних часопросторових характеристик.

Висновки. Основною для Шмітта $\epsilon$ реабілітація загальнолюдських морально-етичних цінностей. Художній метод французького пись- менника Е.-Е. Шмітта відрізняє його від інших митців сучасності прагненням дистанціюватися від постмодерністських тенденцій у літературі. Письменник у своїх творах створює світ, повний оптимізму і надії, яких позбавила людину естетика постмодернізму.

В епоху, коли мистецтво перебуває на межі втрати ідейного наповнення та глибинного сенсу, Шмітт, використовуючи у своїй творчості правила «гарної гри», дотримується, проте, думки, що мистецтво повинно бути функціональним. Йому, як і просвітителям, більше до смаку, якщо читач скаже йому не «браво», а «спасибі» за реальну користь його книг. Цінності та філософські погляди, які запозичив Шмітт в епохи Просвітництва, виявляються у філософічності змісту п’єси «Гість», вільній маніпуляції елементами різних жанрових форм, у концепції головного героя твору.

Розглядаючи цю епоху як джерело ідейного та художнього збагачення, Шмітт не втрачає свою творчу індивідуальність.

\section{СПИСОК ВИКОРИСТАНИХ ДЖЕРЕЛ}

1. Блінніков М. В. Великі філософи: словник-довідник. Логос, 1999. С. 135-136.

2. Зарва В. А. Просвітництво: тлумачення, витоки, сутність. Київ : Слово і час, 2009. 54 с.

3. Кірєєва Н. В. Постмодернізм у зарубіжній літературі : навчальний комплекс для студентів філологів. Флінта, 2004. $200 \mathrm{c}$.

4. Ковалів Ю. І. Літературознавча енциклопедія у двох томах : енциклопедія у 2 т. Київ : Видавничий центр «Академія», 2007. Т. $1.246 \mathrm{c.}$

5. Маньковська Н. Б. Постмодернізм. Культурологія. ХХ століття : енциклопедія у 2 т. ТОВ «Алетейя», 1998. T. 2. C. $130-132$.

6. Покотілова О. I. Ідеї Просвітництва в культурі Франції XVIII століття. Іноземні мови в школах України. 2016. $120 \mathrm{c}$.

7. Schmitt Eric-Emmanuel. Théâtre: La Nuit des Valognes, Le Visiteur, Le Bâillon, L’Ecole du diable. Paris, 2007. 98 p.

8. Schmitt Eric-Emmanuel. Le Visiteur. Paris: Magnard, 2002. 18 p.

\section{REFERENCES}

1. Blinnikov M. V. Velyki filisofy: slovnyk-dovidnyk [Great philosophers: a dictionary - a reference book]. Logos, 1999. P. 135-136 [in Ukrainian].

2. Zarva V. A. Prosvitnytstvo: tlumatchenia, vitoki, sutnist` [Enlightenment: interpretation, origins, essence]. Kyiv : Word and time, 2009. P. 54 [in Ukrainian].

3. Kireeva N. V. Postmodernism u zarubijniy literature [Postmodernism in foreign literature]. Educational complex for students of philology. Flinta. 2004. P. 200 [in Ukrainian].

4. Kovaliv Y. I. Literaturoznavcha enciklopediya u dvoh tomah [Literary encyclopedia in two volumes]. Encyclopedia in 2 vol. Publishing centre "Academy", 2007. P. 246 [in Ukrainian].

5. Mankovska N. B. Postmodernism. Kulturologiya. XX stolitya [Postmodernism. Culturology. XX century]. "Aletheia", 1998. Vol. 2. P. 130-132 [in Ukrainian].

6. Pokotilova O. I. Idei Prosvitnytstva v kulturi Frantsii XVIII stolittya [Ideas of the Enlightenment in the culture of France in the XVIII century]. Foreign languages in Ukraine. 2016. P. 120 [in Ukrainian].

7. Schmitt Eric-Emmanuel. Théâtre: La Nuit des Valognes, Le Visiteur, Le Bâillon, L'Ecole du diable [Theater: The night in the Valognes, The Visitor, The Bâillon, The Devil's School]. Paris, 2007. P. 98 [in French].

8. Schmitt Eric-Emmanuel. Le Visiteur [The Visitor]. Paris. Magnard, 2002. P. 18 [in French] 